\title{
ANALISIS VALUE CHAIN SYSTEM DAN STRATEGY PEMASARAN RUMPUT LAUT DI KABUPATEN MALUKU TENGGARA (Analyze Value Chain System and Seaweed Marketing Strategy in North East Maluku District)
}

\author{
Anna Maria Ngabalin \\ PoliteknikPerikanan NegeriTual,edha_143@yahoo.com
}

Diterima/disetujui : 29 Maret 2014/ 15 Mei 2014

\begin{abstract}
Potential land in Southeast Maluku regency, Maluku Province, is one of the means in the seaweed cultivation and production. Additionally, as most people work as fishermen, theireconomic situation is getting improved although it is not yetin accordance with the target of maximum achievement at the level of life necessities. To increase the production and marketing of seaweed, this study usedthe Value Chain System which analyzedmain activities include the process of Nurseries, Operations, Logistics and phase of marketing and sales which are supported by Infrastructure, Human Resource Management, and Development of Seaweed Technology. In the description of the Value Chain, theanalysisof added-valuewas also performed on each main actor with a value of Rp. 288 to fishermen, Rp. 550 to Small Scale Traders, and Rp.850 to LargeScale Traders. The determination of the marketing strategy using SWOT analysis (Strengths, Weaknesses, Opportunities and Threats) produced the alternative marketing strategies in strategy formulation. It was concluded based on internal and external factors in the seaweed production and marketing processes. In this context, the analysis of the value chain system was critical to improve the market access and to ensure a more efficient flow of products, as well asto ensure that all actors benefit proportionally, according to their contributions.
\end{abstract}

Keywords: Value Chain, Seaweed Marketing, SWOT

\section{Pendahuluan}

Rumput laut merupakan salah satu komoditi ekspor yang potensial untuk dikembangkan. Saat ini Indonesia masih merupakan salah satu negara eksportir penting di Asia karena rumput laut tumbuh dan tersebar hampir diseluruh perairan Indonesia. Rumput laut masih banyak diekspor dalam bentuk bahan mentah yaitu berupa rumput laut kering tetapi tidak semua bermanfaat bagi manusia. Rumput laut yang banyak dimanfaatkan adalah dari jenis ganggang merah dan ganggang cokelat karena mengandung agar-agar, keraginan, porpiran, dan furcelaran. Menurut Kementrian Kelautan dan Perikanan (2012) sebanyak $70 \%$ produksi bahan mentah rumput laut kering di ekspor ke China, Uni Eropa, dan Filipina. Pasar dalam negeri masih menyerap $30 \%$ bahan mentah rumput laut kering.

Walaupun dalam dua tahun terakhir ini produksi rumput laut kering di Kabupaten Maluku Tenggara sangat mengalami peningkatan, namun kondisi perdagangan rumput laut sangat berpotensi besar menjadi permainan pedagang pengumpul. Ini terjadi karena peran pedagang pengumpul sangat besar bagi terlaksananya perdagangan rumput laut dari nelayan ke pedagang besar dan pasar ekspor. Secara empiris di lapangan seringkali dijumpai bahwa para nelayan produsen tampaknya tetap saja menghadapi fluktuasi harga terutama saat melakukan aktifitas penjualan dalam pemasaran. 
Sistem pemasaran yang efisien juga harus dapat membentuk harga pasar yang saling berkaitan dengan perubahan tempat melalui biaya pengangkutan, perubahan bentuk melalui biaya pengolahan dan perubahan waktu melalui biaya penyimpanan. Dalam konteks ini, analisis sistem rantai nilai sangat penting untuk meningkatkan akses pasar dan memastikan arus produk yang lebih efisien, serta menjaga agar semua pelaku mendapat manfaat yang proporsional sesuai dengan kontribusinya.

Berdasarkan uraian di atas permasalahan yang akan dikaji dalam penelitian ini adalah:

1. Bagaimanakah system rantai nilai produk olahan rumput laut di Kabupaten Maluku Tenggara saat ini?

2. Bagaimana bentuk strategi pemasaran produk olahan rumput laut yang harus digunakan agar dapat terciptanya proses pemasaran yang efisien?

Berdasarkan perumusan masalah di atas, maka tujuan yang ingin dicapai dalam penelitian ini adalah:

1. Mempelajari sistem rantai nilai produk olahan rumput laut di Kabupaten Maluku Tenggara saat ini,

2. Menganalisis dan menentukan strategi pemasaran produk olahan rumput laut di Kabupaten Maluku Tenggara agar dapat menciptakan proses pemasaran yang efisien.

Agar tidak terjadi kerancuan dalam mencapai tujuan penelitian, maka penelitian ini dibatasi pada analisis rantai nilai produksi rumput laut yang terdiri dari aktifitas utama maupun aktifitas pendukung yang dikhususkan pada desa percontohan di Kabupaten Maluku Tenggara serta alternatif strategi pemasaran yang dapat menciptakan efisiensi sistem pemasaran yang ditentukan dari Analisis Strenghts, Weaknesses, Opportunities, dan Threats (SWOT)

\section{METODOLOGI}

Aktivitas rantai nilai merupakan balok pembangunan keunggulan bersaing. Aktivitas nilai dihubungkan dengan keterkaitan di dalam rantai nilai. Alternatif strategi pemasaran dianalisis dan ditentukan menggunakan metode SWOT dengan memperhatikan tiap uraian pemetaan rantai nilai yang diharapkan dapat memperbaiki tata niaga sehingga lebih terstruktur serta pengolahan komoditi unggulan di masingmasing daerah percontohan yang dampaknya adalah memaksimalkan hasil komoditi..

Penelitian ini dilaksanakan di Kabupaten Maluku Tenggara dikhususkan pada desa percontohan budidaya rumput laut yakni Desa Letvuan dan Desa Sathean Kecamatan Kei Kecil Kabupaten Maluku Tenggara, Provinsi Maluku yang dilakukan dari Juli sampai dengan Agustus 2012.

Data yang dikumpulkan dan digunakan dalam penelitian berupa:

1. Data Primer. Data ini diperoleh dari pengamatan langsung dengan mengikuti kegiatan operasional meliputi pembibitan sampai dengan pemasaran dan penjualan, serta wawancara langsung dengan pelaku rantai nilai untuk mendapatkan data sekunder.

2. Data Sekunder. Data ini diperoleh laporan berupa informasi perusahaan, instansi terkait dan literatur-literatur yang menunjang topik penelitian. Data sekunder yang diperlukan antara lain: a) Perkembangan lima tahun terakhir hasil produksi rumput laut, b) Populasi masyarakat pesisir dari desa percontohan, c) Perkembangan harga rumput laut yang di jual dari beberapa tahun terakhir di Kabupaten Maluku Tenggara. 


\section{Penentuan Jumlah Sampel dan Metode Pemilihan Sampel}

Pengambilan sampel menggunakan metode purposive sampling, responden yang dipilih merupakan responden yang berkompeten dalam rantai nilai. Jumlah responden yang di pilih memiliki pengalaman kerja minimal satu tahun, dapat memberi gambaran informasi tentang peluang dan ancaman eksternal yang dihadapi dan disesuaikan. Responden yang dipilih 41 orang. Supplier/penyedia sarana sebanyak 8 orang, nelayan rumput laut dan pengelola rumput laut sebanyak 24, pedagang pengumpul lokal 6 orang dan instansi terkait sebanyak 3 orang.

\section{Pengolahan dan Analisis Data}

Aktivitas rantai nilai dari produk industri olahan rumput laut dipetakan menggunakan metode survei dan wawancara terhadap aktor pelaku rantai nilai baik dalam aktifitas utama maupun aktifitas pendukung produksi olahan rumput laut. Setelah diperoleh gambaran tentang rantai nilai, informasi tentang permasalahan dan peluang dapat terlihat pada rantai nilai tersebut.

a. Value Chain Analysis Produk Olahan Rumput Laut di Kabupaten Maluku Tenggara

Rantai nilai produk rumput laut yang ada di Kabupaten Maluku Tenggara dapat dibagi menjadi aktivitas utama dan pendukung. Berikut ini merupakan gambaran umum dari bentuk value chain dalam aktivitas utama dari produk rumput laut yang ada di Kabupaten Maluku Tenggara. Disajikan dalam gambar 1

b. Analisis Nilai Tambah

Cara yang digunakan untuk menghitung nilai tambah dengan melihat pada faktor teknis yang berpengaruh adalah kapasitas produksi, jumlah bahan baku yang digunakan dan tenaga kerja, sedangkan faktor pasar yang berpengaruh adalah harga output, upah tenaga kerja, harga bahan baku dan nilai input yang terdapat dalam proses pengolahan rumput laut yang disesuaikan dengan margin tataniaga.

c. Analisis Matriks SWOT

Menurut David (2010) Matriks SWOT merupakan alat pencocokan yang penting untuk membantu manajer mengembangkan empat jenis strategi, yaitu (1) Strategi SO (kekuatan-peluang) memanfaatkan kekuatan internal perusahaan untuk menarik keuntungan dari peluang eksternal; (2) Strategi WO (kelemahan-peluang) bertujuan untuk memperbaiki kelemahan internal dengan cara mengambil keuntungan dari peluang eksternal; (3) Strategi ST (kekuatan-ancaman) menggunakan kekuatan sebuah perusahaan untuk menghindari, atau mengurangi dampak ancaman eksternal; (4) Strategi WT (kelemahan-ancaman) merupakan taktik defensif yang diarahkan untuk mengurangi kelemahan internal dan menghindari ancaman eksternal. 


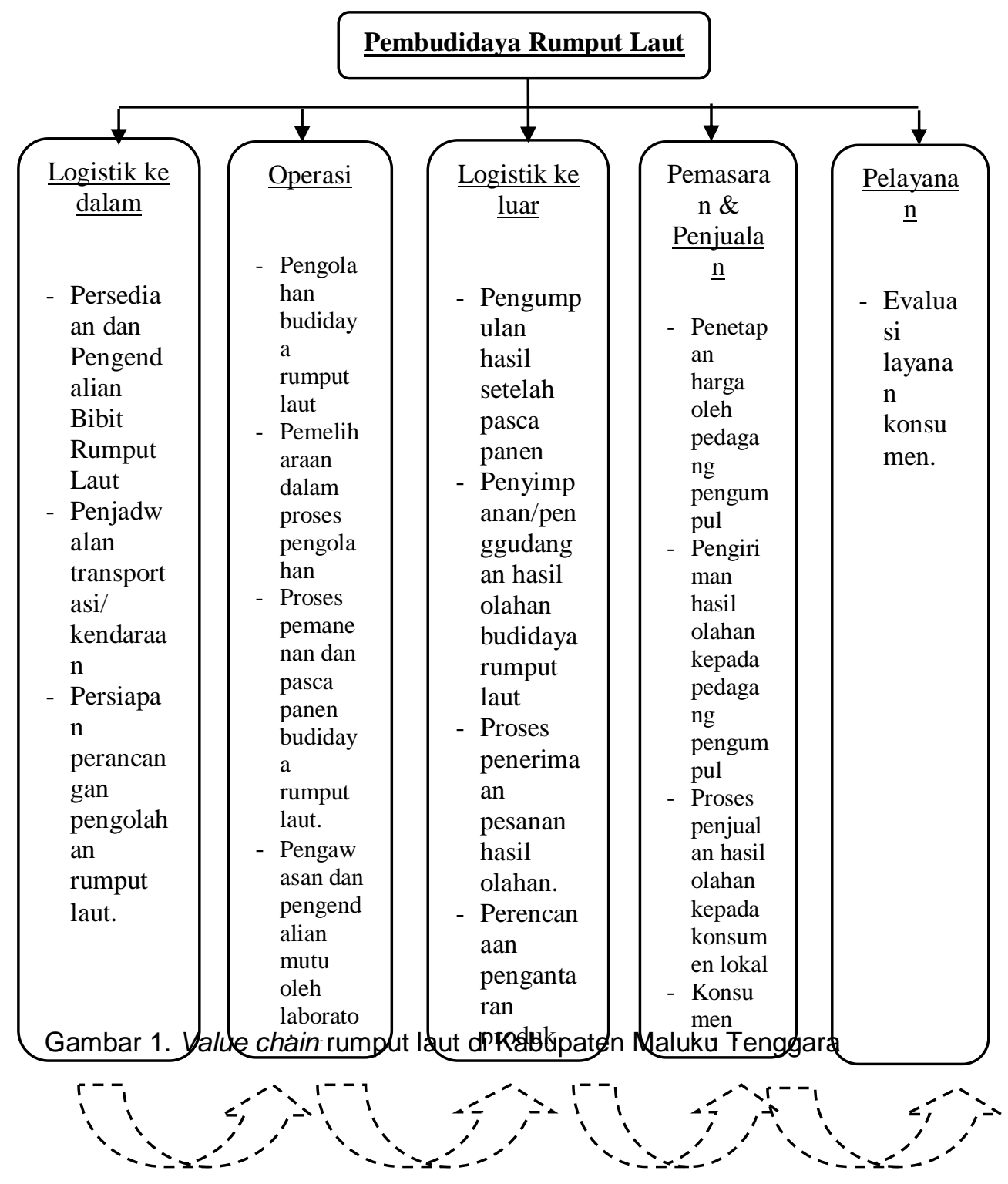

HASIL DAN PEMBAHASAN

\section{Produksi Rumput Laut}

Kondisi parameter lingkungan merupakan kriteria utama dalam penilaian kesesuaian lahan budidaya ikan kerapu dan budidaya rumput laut, disamping aspek lainnya seperti aspek sosial dan ekonomi masyarakat. Upaya pemanfaatan secara terpadu berarti dengan mempertimbangkan berbagai keselarasan dengan aktivitas ekonomi lainnya yang sudah ada. Data produksi rumput laut dari tahun 2009 s.d. 2012 di Kabupaten Maluku Tenggara disajikan pada Tabel 1 dan Perkembangan Harga Penjualan Rumput Laut disajikan pada tabel 2. 
Tabel 1. Hasil Produksi Rumput Laut dalam Tahun 2009-2012 di Kab. Maluku Tenggara.

\begin{tabular}{|c|r|r|}
\hline Tahun & \multicolumn{2}{|c|}{ Produksi } \\
\cline { 2 - 3 } & $\begin{array}{c}\text { Volume } \\
\text { (ton) }\end{array}$ & Nilai (Rp) \\
\hline 2009 & 44.1 & $220.500 .000,-$ \\
\hline 2010 & 381.12 & $3.811 .200 .000,-$ \\
\hline 2011 & 3.285 & $32.850 .000 .000,-$ \\
\hline 2012 & 4.872 .9 & $48.729 .091 .250,-$ \\
\hline
\end{tabular}

Sumber : Dinas Kelautan dan Perikanan Kabupaten Maluku Tenggara tahun (2012).
Tabel 2. Perkembangan Harga Jual rumput laut Rumput Laut dalam Tahun 2009-2012 di Kab. Maluku Tenggara.

\begin{tabular}{|c|c|}
\hline Tahun & $\begin{array}{c}\text { Harga } / \mathrm{Kg} \\
(\mathrm{Rp})\end{array}$ \\
\hline $\mathbf{2 0 0 9}$ & 5.000 \\
\hline $\mathbf{2 0 1 0}$ & 10.000 \\
\hline $\mathbf{2 0 1 1}$ & 10.000 \\
\hline $\mathbf{2 0 1 2}$ & 10.000 \\
\hline
\end{tabular}

Sumber : Dinas Kelautan dan Perikanan Kabupaten Maluku Tenggara tahun (2012).

\section{Pemetaan pelaku dalam value chain system budidaya rumput laut}

a. Nelayan budidaya rumput laut di Maluku Tenggara. Desa Letvuan mencapai 820 orang dan Desa Sathean 485 orang yang tergabung dalam usaha perorangan atau kelompok.

b. Pedagang pengumpul lokal budidaya rumput laut. Terdapat dua bentuk pedagang pengumpul lokal diantaranya pedagang pegumpul skala kecil dengan jumlah tenaga kerja 2-3 orang dan pedagang pengumpul skala besar dengan jumlah tenaga kerja 5-6 orang.

c. Pemerintah daerah dan dinas terkait. Pemerintah daerah mengupayakan programprogram pembudidayaan rumput laut dalam hal ini instansi terkait seperti dinas kelautan dan perikanan yang bekerja sama dengan dinas perindustrian dan perdagangan dalam rencana pembangunan jangka menengah.

\section{Struktur Value Chain System budidaya rumput laut di Kabupaten Maluku Tenggara}

Struktur value chain system budidaya rumput laut di Kabupaten Maluku Tenggara disajikan pada Tabel 3 dan 4. Bagian dari Struktur Value Chain System diantaranya uraian tentang aktifitas utama dan aktifitas penunjang.

Tabel 3 Aktifitas Utama Value Chain System

\begin{tabular}{|c|c|c|c|}
\hline \multirow[b]{2}{*}{ Aktifitas } & \multicolumn{3}{|c|}{ Pelaku Rantai Nilai } \\
\hline & Nelayan & $\begin{array}{c}\text { Pengumpul Skala } \\
\text { Kecil }\end{array}$ & $\begin{array}{l}\text { Pengumpul Skala } \\
\text { Besar }\end{array}$ \\
\hline Pembibitan & $\begin{array}{l}\text { Menghasilkan bibit } \\
\text { sendiri }\end{array}$ & & \\
\hline Operasional & $\begin{array}{l}\text { Proses pengolahan, } \\
\text { pemeliharaan, } \\
\text { pengawasa, panen }\end{array}$ & & \\
\hline Penjualan & $\begin{array}{l}\text { Menjual hasil budiaya } \\
\text { rumput laut ke } \\
\text { pedagang pengumpul }\end{array}$ & $\begin{array}{l}\text { Menjual hasil budiaya } \\
\text { rumput laut ke } \\
\text { pengumpul besar }\end{array}$ & $\begin{array}{l}\text { Menjual hasil budiaya } \\
\text { rumput laut ke } \\
\text { pengecer }\end{array}$ \\
\hline Pembelian & & $\begin{array}{l}\text { Membeli dari nelayan } \\
\text { dengan harga per } \mathrm{Kg} \\
\text { Rp. } 6.000\end{array}$ & $\begin{array}{l}\text { Membeli dari pedagang } \\
\text { pengumpul kecil } \\
\text { dengan harga } \mathrm{Rp} \text {. } \\
7.500 / \mathrm{Kg}\end{array}$ \\
\hline Pengangkutan & $\begin{array}{l}\text { Nelayan } \\
\text { memindahkan hasil } \\
\text { panen ke } \\
\text { penggudagan }\end{array}$ & $\begin{array}{l}\text { Mengangkut hasil } \\
\text { panen dari nelayan } \\
\text { untuk dijual ke } \\
\text { pedagang pengumpul } \\
\text { besar }\end{array}$ & $\begin{array}{l}\text { Mengangkut pembelian } \\
\text { hasil panen dari } \\
\text { pedagang pengumpul } \\
\text { kecil untuk dijual } \\
\text { pengecer }\end{array}$ \\
\hline
\end{tabular}


Tabel 4 Aktifitas Penunjang Value Chain System

\begin{tabular}{|c|c|c|}
\hline \multirow{4}{*}{ 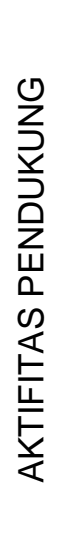 } & Infrastruktur & $\begin{array}{l}\text { Pabrik dalam proses penyelesaian, sarana } \\
\text { transportasi cukup memadai, tetapi ketersedian jalan } \\
\text { masih belum memadai. }\end{array}$ \\
\hline & $\begin{array}{l}\text { Sumber Daya } \\
\text { Manusia }\end{array}$ & \begin{tabular}{l}
\multicolumn{4}{c}{ Adanya pelatihan-pelatihan yang disediakan Dinas } \\
Kelautan dan Perikanan bekerjasama dengan \\
Kementerian Kelautan dan Perikanan Pusat.
\end{tabular} \\
\hline & $\begin{array}{l}\text { Pengembangan } \\
\text { Teknologi }\end{array}$ & $\begin{array}{l}\text { Bantuan alat-alat pabrik serta pemudidayaan } \\
\text { rumput laut untuk daerah telah disediakan oleh } \\
\text { Kemnterian Kelautan dan Perikanan Pusat. }\end{array}$ \\
\hline & Pembelian & $\begin{array}{l}\text { Pangsa pasar hasil budidaya rumput laut di daerah } \\
\text { masih sangat minim sehingga pembudidaya tidak } \\
\text { memiliki alternatif untuk menjual hasil. }\end{array}$ \\
\hline
\end{tabular}

\section{Rantai Pemasaran Rumput Laut}

Secara umum mempunyai 5 tahap dalam proses pemasaran pada rumput laut di Kabupaten Maluku Tenggara yang meliputi:

1. Proses pembudidayaan rumput sampai panen dan penanganan pasca panen serta penggudangan laut oleh nelayan,

2. Setelah diperoleh hasil budidaya, maka nelayan menjual hasil tersebut kepada pedagang pengumpul lokal I dengan harga yang telah ditentukan sendiri oleh pedagang pengumpul. yg dimaksud dengan pedagang pengumpul lokal skala kecil disini adalah pedagang yang berada dekat dengan lokasi budidaya dan juga memiliki akses lanjutan untuk mengumpulkan dan mengantar hasil panenan ke pedagang pengumpul yang jauh dari lokasi pembudidayaan.

3. Hasil pembelian dan pengumpulan yang ada pada pedagang pengumpul skala kecil kembali dijual kepada pedagang pengumpul lokal skala besar. Dalam hal ini, pedangan pengumpul lokal skala besar dapat langsung membeli hasil panen budidaya rumput laut pada nelayan, karena rata-rata memiliki modal yang cukup besar untuk menjangkau lokasi-lokasi budidaya.

4. Hasil pembelian yang ada pada pedagang pengumpul seterusnya dijual dan dikirim kepada pengecer yang berada di luar daerah seperti Makassar dan Surabaya melalui transpotasi laut milik pribadi maupun sewaan.

5. Pengecer yang telah membeli hasil panen budidaya rumput laut dapat langsung mengekspor ke luar negeri misalnya Cina dengan harga yang lebih baik.

\section{Analisis Nilai Tambah}

1. Analisis Nilai Tambah pada nelayan menunjukan nilai input nelayan adalah 6212.33 per $\mathrm{kg}$ dengan perolehan nilai tambah pada nelayan dari $1 \mathrm{~kg}$ rumput laut sebesar Rp. 288 dengan uraian disajikan pada Tabel 5. 
Tabel 5 Perhitungan Nilai Tambah Pada Nelayan

\begin{tabular}{lrr}
\hline \multicolumn{3}{c}{ Perhitungan Nilai Tambah } \\
\hline komponen nilai tambah & Nilai (Rp/kg) & $\%$ \\
\hline biaya bahan baku & $5,505,000$ & 86 \\
\hline biaya operasional & $1,270,000$ & 1 \\
\hline Biaya Penyusustan Peralatan dan & 665,000 & 10 \\
Kendaraan & & 96 \\
\hline nilai input & 6,212 & 100 \\
\hline nilai output & 2800 & 4 \\
\hline nilai tambah & & \\
\hline
\end{tabular}

2. Analisis Nilai Tambah oleh pedagang pengumpul skala kecil sebesar Rp. 550 per $\mathrm{kg}$ dengan uraian disajikan pada Tabel 6 .

Tabel 6 Perhitungan Nilai Tambah Pedagang Pengumpul Kecil Perhitungan Nilai Tambah

\begin{tabular}{|l|c|c|c|}
\hline $\begin{array}{l}\text { Komponen nilai } \\
\text { tambah }\end{array}$ & $\begin{array}{c}\text { Nilai (Rp/ } \\
\mathbf{k g})\end{array}$ & \% \\
\hline Biaya Bahan Baku & 6500 & 0,8667 & 86.67 \\
\hline Biaya Operasional & 400 & 0,0532 & 5.32 \\
\hline Biaya Penyusutan & 50 & 0,0066 & 0,66 \\
\hline Nilai Input & 6.950 & 0,9265 & 92.65 \\
\hline Nilai Output & 7500 & 1.000 & 100 \\
\hline Nilai Tambah & $\mathbf{5 5 0}$ & $\mathbf{0 , 0 7 3 5}$ & $\mathbf{7 . 3 5}$ \\
\hline
\end{tabular}

3. Analisis Nilai Tambah oleh pedagang pengumpul skala besar sebesar Rp. 850 per kg dengan uraian disajikan pada Tabel 7 .

Tabel 7. Perhitungan Nilai Tambah Pedagang Pengumpul Besar

\begin{tabular}{|l|c|c|c|}
\hline \multicolumn{4}{|c|}{ Perhitungan Nilai Tambah } \\
\hline Komponen Nilai Tambah & $\begin{array}{c}\text { Nilai (Rp/ } \\
\mathbf{k g})\end{array}$ & & $\%$ \\
\hline Biaya Bahan Baku & 7.500 & 0,8333 & 83.33 \\
\hline Biaya operasional & 600 & 0,0666 & 6.66 \\
\hline Biaya penyusutan & 50 & 0,0055 & 0,55 \\
\hline Nilai input & 8150 & 0,9054 & 90.54 \\
\hline Nilai output & 9.000 & 1.000 & 100 \\
\hline Nilai tambah & 850 & 0,0946 & 9.46 \\
\hline
\end{tabular}


4. Dalam tabel 5, 6, dan 7 terdapat uraian tentang Analisis Nilai Tambah yang menggunakan acuan metode Hayami pada tiap pelaku rantai nilai yang disesuaikan dengan margin tata niaga menurut Limbong dan Sitorus (1985).

5. Tabel 8 Pembentukan Rantai Nilai Rumput laut di Kabupaten Maluku Tenggara

\begin{tabular}{|l|c|c|c|}
\hline \multicolumn{4}{|c|}{ Pembentukan Rantai Nilai Rumput Laut } \\
\hline \multirow{2}{*}{ Jenis Kegiatan } & Nelayan & $\begin{array}{c}\text { Pengumpul } \\
\text { Kecil }\end{array}$ & $\begin{array}{c}\text { Pengumpul } \\
\text { Besar }\end{array}$ \\
\cline { 2 - 4 } & $\mathbf{R p} / \mathbf{k g}$ & $\mathbf{R p / k g}$ & $\mathbf{R p / k g}$ \\
\hline Produksi & 5.505 .000 & 6500 & 7500 \\
\hline Operasi & 1.270 .000 & 400 & 600 \\
\hline By penyustan & 665.000 & 50 & 50 \\
\hline Total Biaya & 6.212 & 6950 & 8150 \\
\hline Harga jual & 6.500 & 7500 & 9.000 \\
\hline Margin & 288 & 550 & 850 \\
\hline
\end{tabular}

\section{Hasil Analisis SWOT}

Berdasarkan hasil analisis internal diperoleh skor tertimbang 2.474 sedangkan dari hasil analisis eksternal diperoleh skor tertimbang 2.634, maka gabungan dari faktor internal dan faktor eksternal tersebut memperlihatkan posisi obyek yang sedang diteliti yaitu berada pada ruang $\mathrm{V}$ yaitu stabilitas (menjaga dan mempertahankan). Strategi yang layak ditawarkan untuk posisi stabil tersebut yaitu para nelayan dapat melakukan kegiatan penetrasi pasar dan langkah penyempurnaan strategi pengembangan produknya untuk mempertahankan dan memelihara kinerja yang sudah dicapai. Matrix SWOT disajikan dalam Tabel 9.

\section{Formulasi Strategi}

Berdasarkan matriks SWOT di atas maka dapat diambil 4 bagian alternatif strategi adalah sebagaimana terurai sebagai berikut 1) Alternatif strategi pertama strategi SO: nelayan budidaya rumput laut di Kabupaten Maluku Tenggara pada kekuatan memiliki lahan yang potensial tetapi memerlukan Pendampingan dan pelatihan dari pemerintah untuk pengembangan Budidaya dan keterampilan Nelayan sesuai dengan motivasi yang tinggi, 2) Alternatif strategi kedua - strategi WO: diperlukan manajemen pembukuan keuangan yang baik untuk dapat melakukan evaluasi, perencanaan dan pengadministrasian usaha, selain manajemen pembukuan keuangan, pengetahuan SDM yang memadai, 3) Alternatif strategi ketiga - strategi ST: salah satunya dengan cara perencanaan pola tanam yang baik di setiap awal musim tanam membangun kerjasama dengan perusahaan lain untuk memperluas pasar, transportasi, dan menghadapi persaingan serta kerjasama pemerintah dan swasta untuk memanfaatkan infrastruktur pengolahan dan sarana promosi pengembangan budidaya rumput laut di kabupaten maluku tenggara, 4) Strategi keempat - strategi WT: dalam usaha menjamin usaha budidaya rumput laut yang layak secara finansial, perlu terus dilakukan upaya pemberdayaan nelayan pembudidaya sehingga dapat melaksanakan intensifikasi usaha dengan secara baik serta bantuan-bantuan permodalan yang disediakan.

Berdasarkan uraian tersebut maka alternatif strategi terbaik yang dapat diaplikasikan untuk masyarakat Maluku Tenggara saat ini dimana para nelayan budidaya rumput laut telah mendapatkan pelatihan-pelatihan tentang pengembangan budidaya yang juga meliputi pelatihan keterampilan untuk melakukan evaluasi, perencanaan baik dimulai dari pola tanam, membangun kerja sama, cara memanfaatkan infrastruktur 
pengolahan yang telah disediakan pemerintah serta promosi pengembangan budidaya rumput laut sehingga mulai menghasilkan sumber daya manusia yang cukup memadai maka penulis dapat menarik kesimpulan bahwa strategi keempat - strategi WT adalah alternatif strategi pemasaran yang paling tepat menjamin usaha budidaya rumput laut yang layak secara finansial, yang perlu terus dilakukan upaya pemberdayaan nelayan pembudidaya sehingga dapat melaksanakan intensifikasi usaha dengan baik dan memanfaatkan bantuan-bantuan permodalan sehingga usaha budidaya rumput laut ini dapat terus berkembang dengan sistem pemasaran yang lebih dan teratur.

Tabel 9. Matrix SWOT

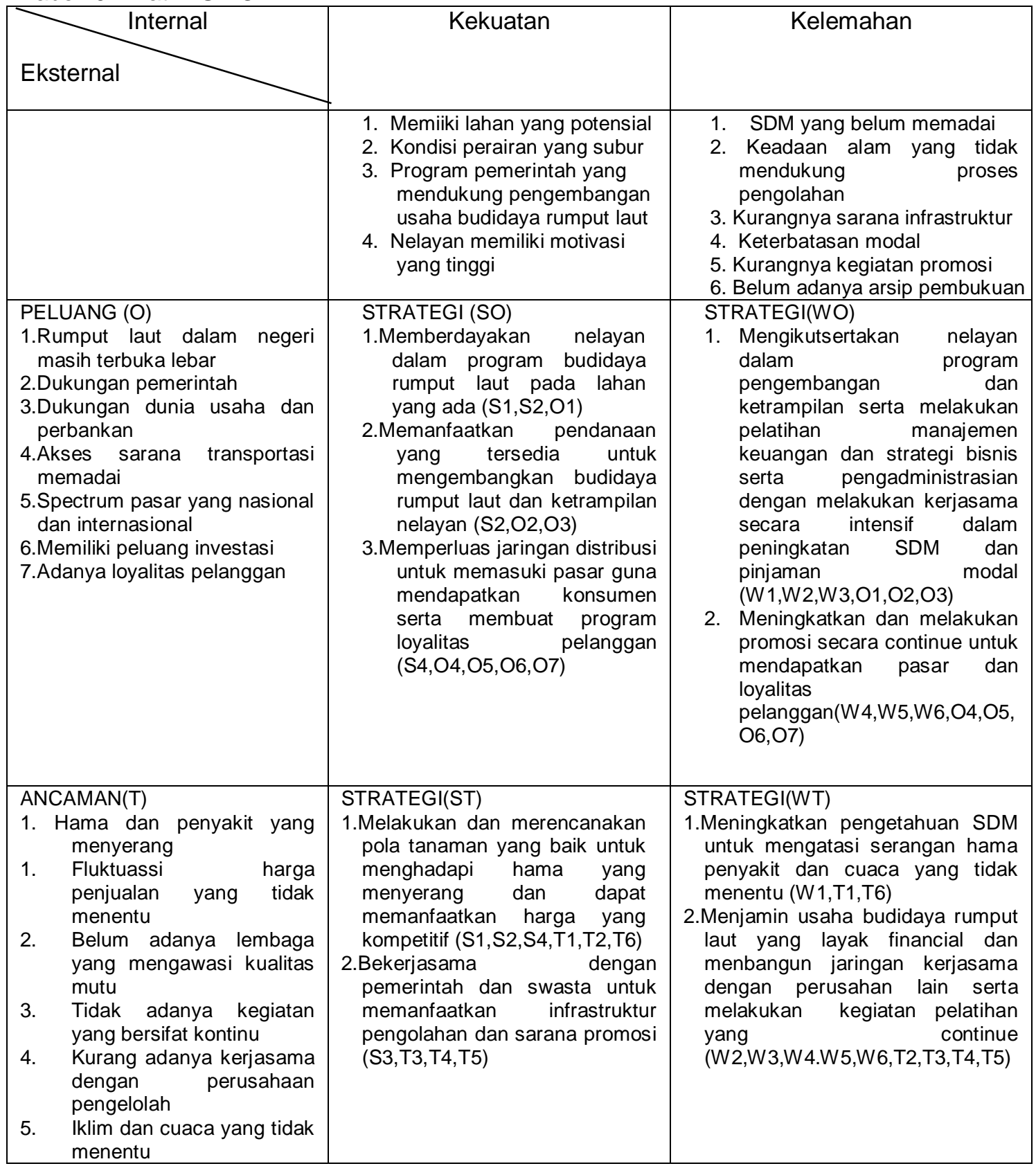




\section{Simpulan dan Saran}

\section{Simpulan}

Berdasarkan hasil penelitian dapat disimpulkan beberapa hal sebagai berikut:

1. Nelayan pembudidaya sebagai pelaku pada sub sistem operasional dalam aktifitas utama value chain system rumput laut yang memiliki pengalaman kerja rata-rata 2 tahun dan pengetahuan yang sederhana dalam mengatasi dan menghindari kerugian yang terjadi dalam proses pengolahan maupun proses pemeliharaan akibat keadaan alam dan kurangnya pengetahuan formal tentang budidaya rumput laut yang baik.

2. Bagian sub sistem pemasaran dan penjualan memiliki rantai tata niaga yang belum memiliki kinerja yang baik karena adanya penentuan harga secara sepihak oleh pedagang pengumpul lokal skala kecil kepada nelayan pembudidaya, begitu pula dengan investasi pasar yang belum dapat dijangkau oleh pemerintah daerah. Adanya program pengembangan sektor produk unggulan oleh pemerintah daerah dengan bantuan-bantuan materiil serta pengembangan sumber daya manusia belum diimbangi dengan infrastruktur yang memadai dalam mengoptimalkan pemanfaatan lahan yang sangat potensial.

3. Hasil analisis SWOT dapat diperoleh analisis internal skor tertimbang 2.474 sedangkan dari hasil analisis eksternal diperoleh skor tertimbang 2.634. Gabungan dari faktor internal dan faktor eksternal (Tabel IFE dan EFE) tersebut memperlihatkan posisi obyek yang sedang diteliti yaitu berada pada ruang $\mathrm{V}$ yaitu stabilitas (menjaga dan mempertahankan). Strategi yang layak ditawarkan untuk posisi stabil tersebut yaitu para nelayan dapat melakukan kegiatan penetrasi pasar dan langkah penyempurnaan strategi pengembangan produknya untuk mempertahankan dan memelihara kinerja yang sudah dicapai.

\section{Saran}

Saran yang dapat disampaikan bagi pengembangan budidaya rumput laut adalah sebagai berikut:

1. Untuk mewujudkan usaha budidaya rumput laut yang berkelanjutan perlu dilakukan penataan terhadap rantai tata niaga yang tidak beraturan, yang tidak sesuai dengan norma industri dan keefisienan pasar. Penataan budidaya rumput laut harus memiliki legalitas melihat semakin meningkatnya pembudidaya rumput laut dalam empat tahun terakhir ini.

2. Strategi pemasaran budidaya rumput laut yang memperhatikan peluang dan kekuatan internal dari value chain system dengan program strategis pengembangan rumput laut yaitu:

a) Pengembangan teknologi melalui kerja sama dengan institusi litbang dan perguruan tinggi dalam hal pengadaan mesin/peralatan (teknologi terapan) dan ahli teknologi yang spesifik untuk pengolahan rumput laut (contohnya teknologi dari luar negeri; perancis).

b) Fasilitasi pendidikan melalui pelatihan dan seminar/workshop dalam rangka peningkatan pengetahuan, keahlian dan teknologi SDM untuk mendukung industri pengolahan.

c) Perlu adanya strategi pengembangan usaha rumput laut ke depan sebagai upaya mengontrol kualitas produk, mengoptimalkan nilai tambah produk, mengeliminasi intervensi harga dari luar, memberi peran kepada stakeholder secara proporsional dan membantu pemerintah daerah di dalam mengembangkan produk unggulan daerah. 
d) Memfasilitasi kemitraan antara pembudidaya dengan investor terhadap akses toknologi, pasar dan modal dan penjaminan kualitas rumput laut dengan mengembangkan laboratorium pengujian.

\section{DAFTAR PUSTAKA}

Aslan L M.1998. Budidaya Rumput Laut. Yogyakarta (ID) : Kanisius.

[Bappeda] Badan Perencanaan dan Pendapatan Daerah Malra.2011. Kabupaten Maluku Tenggara(ID).

[BPS] Badan Pusat Statistik Malra. 2011. Kabupaten Maluku Tenggara (ID).

Cahyani. 2006. Analisis Rantai Nilai dan Determinan Keunggulan Kompetitif Ayam Ras Pedaging di Kabupaten Bogor [Tesis] Bogor (ID): Institut Pertanian Bogor.

David FR. 2004. Manajemen Strategis: Konsep-konsep. Edisi Kesembilan. Jakarta (ID): PT INDEKS Kelompok GRAMEDIA_p278.

[DKP] Dinas Kelautan dan Perikanan Malra. 2011. Kabupaten Maluku Tenggara (ID).

Hidayat A. 1994. Budidaya Rumput Laut. Surabaya (ID): Penerbit Usaha Nasional.

Kotler P, G Amstrong. 2001. Prinsip-Prinsip Pemasaran (Terjemahan). Jakarta (ID): Erlangga

Limbong W H, Sitorus P. 1985. Pengantar Tata Niaga Pertanian. Bogor (ID) : Institut pertanian Bogor

Mochamad AN. 2011. Analisis Rantai Nilai Produk Olahan Buah Manggis [Tesis] Bogor (ID): Institut Pertanian Bogor.

Nontji A. 1993. Laut Nusantara. Jakarta (ID): Djambatan.

Porter ME. 1990. The Competitive Advantage of Nations. New York (US): The Free Press.

Rangkuti F. 2005. Analisis SWOT Teknik Membedah Kasus Bisnis: Reorientasi Konsep Perencanaan Strategis untuk Menghadapi Abad 21. Jakarta (ID): Penerbit PT Gramedia Pustaka Utama.

Zatnika A. 2000. "Manfaat Pasca Panen dan Pengolahan Rumput Laut". Mataram-NTB (ID): IPTEK Teknologi Budidaya dan Pengolahan Rumput Laut. 